\title{
PHYSIOLOGICAL QUALITY OF Gliricidia sepium (Jacq.) Steud. (LEGUMINOSAE - PAPILIONOIDEAE) SEEDS SUBJECTED TO DIFFERENT STORAGE CONDITIONS ${ }^{1}$
}

\author{
Renata Conduru Ribeiro Reis ${ }^{2}$, Claudinéia Regina Pelacani ${ }^{3}$, Cimille Gabrielle Cardoso Antunes², Bárbara \\ França Dantas ${ }^{4}$ e Renato Delmondez de Castro ${ }^{5}$
}

\begin{abstract}
Studies of seed physiological processes represent the starting point for the sustainable utilization of native or cultivated plant species from the caatinga biome for which germination studies are still scarce. In order to determine adequate methods for the conservation of Gliricidia sepium seeds, the physiological quality of propagules exposed to different conditions and times of storage were examined. Recently collected seeds of G. sepium were analyzed immediately, while the other sample was stored for three, six, nine, or twelve months in plastic or paper bags under refrigeration or at room temperature for further analysis. The germination rates of seeds from each storage regime were determined and these rates compared to their water content. It was observed that germination capacity was directly related to changes in seed humidity. Storing seeds in plastic bags yielded the best conservation, mainly when they were stored at low temperatures. However, even at temperatures near $25^{\circ} \mathrm{C}$ it was possible to prolong seed viability when their water content was controlled through the use of impermeable packing.
\end{abstract}

Keywords: Germination, Gliricidia e Physiological quality.

\section{QUALIDADE FISIOLÓGICA DE SEMENTES DE Gliricidia sepium (Jacq.) Steud. (LEGUMINOSAE - PAPILIONOIDEAE) SOB DIFERENTES CONDIÇÕES DE ARMAZENAMENTO}

\begin{abstract}
RESUMO - Estudos dos processos fisiológicos de sementes são efetivamente o ponto de partida para a utilização e exploração sustentável de espécies nativas ou cultivadas do bioma Caatinga, cujos trabalhos sobre germinação ainda são escassos. Visando contribuir para o estabelecimento de métodos de conservação de sementes de Gliricidia sepium, este trabalho foi realizado com o objetivo de avaliar a qualidade fisiológica das sementes, submetidas a diferentes condições e períodos de armazenamento. Sementes de gliricidia recém-coletadas foram imediatamente analisadas, sendo as demais armazenadas por três, seis, nove e 12 meses em sacos plásticos e de papel em geladeira e na temperatura ambiente, para análise posterior. Em cada ambiente e período de armazenamento testados foi analisada a taxa de germinação, relacionando-a com o teor de água das sementes. Observou-se que a capacidade germinativa de sementes de gliricidia está totalmente relacionada à tolerância da espécie ao ganho ou à perda de umidade das sementes. O armazenamento em saco plástico foi o que proporcionou melhores condições de conservação das sementes, principalmente quando acondicionadas em temperaturas baixas. No entanto, mesmo em temperaturas em torno de $25{ }^{\circ} \mathrm{C}$ é possível prolongar a viabilidade das sementes de gliricidia, quando se controla o seu teor de água inicial com a utilização de embalagens impermeáveis para o armazenamento.
\end{abstract}

Palavras-chave: Germinação, Teor de água, Qualidade fisiológica e Gliricidia.

\footnotetext{
${ }^{1}$ Recebido em 22.09.2009 e aceito para publicação em 29.03.2012

${ }^{2}$ Programa de Pós-Graduação em Botânica pela Universidade Estadual de Feira de Santana, UEFS, Brasil. E-mail: < rconduru@gmail.com> e<cimillebio@gmail.com>.

${ }^{3}$ Universidade Estadual de Feira de Santana, UEFS, Brasil. E-mail:<claudineiapelacani@gmail.com>.

${ }^{4}$ Empresa Brasileira de Pesquisa Agropecuária, EMBRAPA, Brasil. E-mail: <barbara@cpatsa.embrapa.br>.

${ }^{5}$ Universidade Federal da Bahia, UFBA, Brasil. E-mail: <renatodel@gmail.com>.
} 


\section{INTRODUCTION}

Gliricidia [(Gliricidia sepium (Jacq.) Steud.) (Leguminosae - Papilionoideae)] is a native species of Central and South America. It was introduced into northeastern Brazil in the 1980's and has since become the object of significant commercial and economic interest for the region, due to its multiple uses - which include its use as a forage species with high nutritive value for grazing animals and bees as well, and as a medicinal plant. Drought resistance is one of the most important characteristics of any plant that is to be cultivated in the caatinga region. Gliricidia stands out in this respect because of its ability to be easily propagated by seed and because of its rapid growth, high capacity for regeneration, resistance to drought, among other characteristics (DRUMOND and CARVALHO FILHO, 1999).

Studies of seed physiological processes, including germination studies, represent the starting point for the sustainable use of native or cultivated plant species from the caatinga region. The seeds of a majority of all cultivated species demonstrate orthodox characteristics, in which an increase in their water content during storage will result in a rapid loss of viability and a reduced germination percentage. The conservation potential of any seed depends directly on its physiological quality before the storage period. Desiccation tolerance is acquired progressively during seed development. Among orthodox seeds, desiccation tolerance occurs before the seeds go through any severe reduction in water content - but it is not yet possible to determine if this capacity is acquired beforehand, or if it is directly due to water loss (BEWLEY and BLACK, 1994).

Seed storage involves a series of procedures designed to preserve germination quality. However, good results depend as much on the nature of the seeds themselves as on the storage conditions (SANTANA, 2007). The packaging used in storing seeds plays an important role in the maintenance of their initial vigor. Additionally, environmental humidity and storage temperature can also influence the maintenance of seeds viability (WARD and POWELL, 1983).

Information about the water content of seeds allows one to choose the most adequate procedures, from harvesting to storage that will preserve their physical, physiological and sanitary qualities. This information may also aid in the identification of procedural problems that might arise, as well as in the adoption of adequate responses (MARCOS FILHO et al., 1987). Seed conservation is very important, and adequate storage will diminish the rates of their irreversible deterioration (DELOUCHE et al., 1973; MELO et al., 1979; CABRAL et al., 2003).

Seed deterioration occurs at molecular, genetic, cellular, tissue, and population levels (MATTHEWS, 1985). It is a process that cannot be avoided, only controlled, and this is the principal objective of all storage protocols. Seed storage represents one of the most utilized strategies of ex situ species conservation as it preserves the genetic characteristics of the seeds until they are sown (CARNEIRO, 1985; NODARI et al., 1998).

The present evaluated the conservation of viability of gliricidia seeds using low-technology storage conditions that would be available to poor rural farmers.

\section{MATERIAL AND METHODS}

\subsection{Obtaining and storing seeds}

Mature seeds were collected in 2006 from Gliricidia sepium trees on Fazenda Morrinhos Farm located in the municipality of Queimadas, Bahia State, Brazil (39 40 'W x $11^{\circ} 12^{\prime}$ 's), which had been declared a 'Private Nature Reserve' under the Brazilian law. The seed were collected from newly opening pods and dried in the open air in the semiarid caatinga region of northeastern Brazil. Samples of the recently collected seeds were cleaned and analyzed for their water content and germination rate.

The remaining seeds were placed into either paper or plastic bags and stored at room temperature $\left(25^{\circ} \mathrm{C} \pm 3\right)$ or under refrigeration $\left(8^{\circ} \mathrm{C} \pm 2\right)$ for three, six, nine, or twelve months in the Germination Laboratory of the Horto Florestal Experimental UnitUEFS - Feira de Santana, Bahia State, Brazil, for posterior evaluation.

\subsection{Germination tests}

After each experimental storage period, four sub-samples of 25 seeds were sown in Petri dishes containing two layers of germination paper moistened with a quantity of distilled water corresponding to 2.5 times the weight of the paper substrate. The seeds were maintained in germination chambers at $25^{\circ} \mathrm{C}$ with a 
photoperiod of $14 \mathrm{~h}$ for ten days. The seeds were examined daily and were considered to have germinated when the radicule protruded at least $2 \mathrm{~mm}$ from the seed coat.

\subsection{Water content}

The seed water content was assessed after all storage periods by drying ovens at $105^{\circ} \mathrm{C} / 24 \mathrm{~h}$ (BRASIL, 1992), in four replicates of 25 seeds for each package type and storage temperature.

\subsection{Statistical analyses}

Data related to water content and germination was expressed as percentages, with standard errors. The total germination, average germination time, average germination rate, and germination rate data were transformed by the function $(x+0.5)^{0.5}$ and submitted to variance analysis using the Sisvar 4.3 software program (FERREIRA, 2000). Differences between the averages were compared using the Tukey test at a 5\% probability level.

\section{RESULTS}

While germination percentages changed in response to storage time and the packaging material used, the average germination time remained essentially constant (Table 1) and independent of these two variables.

Based on percentage germination, plastic bags provided the best conditions for seeds stored under both cold and room temperatures. However, seeds stored at room temperature in plastic or paper bags demonstrated a significant decrease in germination potential starting at nine months (Table 2).

Table 1 - Variance analysis of the germination percentage (G), average germination time (Tm), average germination speed $(\mathrm{Vm})$, and germination speed index (IVG) of stored Gliricidia sepium seeds.

Tabela 1 - Análise de variância da porcentagem de germinação $(G)$, tempo médio de germinação (Tm), velocidade média de germinação $(\mathrm{Vm})$ e índice de velocidade de germinação (IVG) de sementes de Gliricidia sepium armazenadas.

\begin{tabular}{lcccc}
\hline Variable & G \% & Tm, days & Vm, days ${ }^{-1}$ & IVG \\
\hline Storage time & $74.01^{*}$ & $1.143^{\mathrm{ns}}$ & $41.336^{*}$ & $125.77^{*}$ \\
Environments & $132.97^{*}$ & $0.643^{\mathrm{ns}}$ & $75.075^{*}$ & $216.67^{*}$ \\
Time* Environ. $^{*}$ & $52.46^{*}$ & $0.337^{\mathrm{ns}}$ & $4.569^{*}$ & $36.37^{*}$ \\
\hline CV\% & 7.85 & 24.26 & 3.12 & 5.67 \\
\hline
\end{tabular}

$\mathrm{ns}=($ not significant $) ;{ }^{*}=$ significant to a $5 \%$ level.
Changes in water content of Gliricidia sepium seeds over time during storage depended on the type of packaging used. The initial seed water content was $6.4 \%$, and this percentage was maintained for the entire period in which the seeds were stored in the refrigerator in plastic bags. High germination rates were observed (94\%) even after 12 months of storage under these conditions (Figure 1A).

The germination capacity of any species is very dependent on its tolerance to gaining or losing seed humidity. Figure $1 \mathrm{~B}$ shows that germination decreased when the water content of $G$. sepium seeds attained lower than initial levels. Seeds stored in paper bags at room temperature demonstrated gains in water content after six months of storage (Figure 1D), and a concomitant lose of viability. According to Ribeiro (2008), this loss of viability points to alterations in seed carbohydrate reserves resulting from increasing water content.

Under low temperature conditions (refrigeration), gliricidia seeds stored in impermeable (plastic) bags (Figure 1A) and permeable (paper) bags (Figure 1B) demonstrated high germination rates and high average germination speed up to one year after initial storage (Table 2). Seeds stored at room temperature demonstrated a decrease in their average germination speed during the year, independent of the packaging used, as well as a decrease in the germination percentage (Table 2). Significant reductions in all of these parameters were observed starting in the sixth month of storage.

Significant differences in the seeds germination rate index were observed when the seeds were stored at room temperature in paper bags - but only after six months of storage (Table 1 ). This reduction in germination rate index can be attributed to a loss of vigor in seeds kept under uncontrolled environmental conditions, in comparison to storage in plastic bags at cold temperatures.

These results suggest that storing gliricidia seeds at low temperatures and in impermeable packages is much more suitable than holding them at room temperature and in permeable packaging, with seeds subjected to the latter conditions demonstrating much higher losses of viability.

Revista Árvore, Viçosa-MG, v.36, n.2, p.229-235, 2012 
Table 2 - Germination percentage (G), average time (Tm), average speed (Vm), and germination speed index (IVG) of recently collected Gliricidia sepium seeds (RC) stored in a refrigerator in plastic bags (RPB) or in paper bags (RPPB); or stored at room temperature in plastic bags (TRPB) or in paper bags (TRPPB).

Tabela 2 - Porcentagem de germinação $(G)$, tempo médio (Tm), velocidade média (Vm) e índice de velocidade de germinação $(I V G)$ de sementes de Gliricidia sepium recém-coletadas $(R C)$ e armazenadas em geladeira em saco plástico (GSPL) e saco de papel (GSPP) e em temperatura ambiente em saco plástico (ASPL) e em saco de papel (ASPP).

\begin{tabular}{|c|c|c|c|c|c|c|}
\hline \multicolumn{7}{|c|}{ Months } \\
\hline Environments & 0 & 3 & 6 & 9 & 12 & Average \\
\hline \multicolumn{7}{|c|}{$\mathrm{G}(\%)$} \\
\hline $\mathrm{RC}$ & $100 \mathrm{aA}$ & --- & --- & --- & --- & $100 \mathrm{~A}$ \\
\hline RPB & --- & $96.00 \mathrm{aA}$ & $98.00 \mathrm{aA}$ & $89.00 \mathrm{aAB}$ & $94.00 \mathrm{aA}$ & $94.25 \mathrm{AB}$ \\
\hline RPPB & --- & $99.00 \mathrm{aA}$ & $98.00 \mathrm{aA}$ & $93.00 \mathrm{aA}$ & $91.00 \mathrm{aA}$ & $95.25 \mathrm{AB}$ \\
\hline TRPB & --- & $98.00 \mathrm{aA}$ & $96.00 \mathrm{aA}$ & $78.00 \mathrm{bB}$ & $87.00 \mathrm{abA}$ & $89.75 \mathrm{~B}$ \\
\hline TRPPB & --- & $96.00 \mathrm{aA}$ & $86.00 \mathrm{aA}$ & $3.00 \mathrm{bC}$ & $1.33 \mathrm{bB}$ & $49.60 \mathrm{C}$ \\
\hline Average & $100 \mathrm{a}$ & $97.25 \mathrm{a}$ & $94.50 \mathrm{a}$ & $65.75 b$ & $72.80 \mathrm{~b}$ & \\
\hline \multicolumn{7}{|c|}{ Tm, (days) } \\
\hline $\mathrm{RC}$ & $1.490 \mathrm{aA}$ & --- & --- & --- & --- & $1.490 \mathrm{~A}$ \\
\hline RPB & --- & $2.094 \mathrm{aA}$ & $2.294 \mathrm{aA}$ & $2.260 \mathrm{aA}$ & $2.167 \mathrm{aA}$ & $2.204 \mathrm{~A}$ \\
\hline RPPB & --- & $2.121 \mathrm{aA}$ & $2.037 \mathrm{aA}$ & $2.663 \mathrm{aA}$ & $1.964 \mathrm{aA}$ & $2.196 \mathrm{~A}$ \\
\hline TRPB & --- & $2.104 \mathrm{aA}$ & $2.463 \mathrm{aA}$ & $2.837 \mathrm{aA}$ & $2.587 \mathrm{aA}$ & $2.497 \mathrm{~A}$ \\
\hline TRPPB & --- & $2.127 \mathrm{aA}$ & $3.570 \mathrm{aA}$ & $4.500 \mathrm{aA}$ & $2.000 \mathrm{aA}$ & $3.112 \mathrm{~A}$ \\
\hline Average & $1.490 \mathrm{a}$ & $2.112 \mathrm{a}$ & $2.590 \mathrm{a}$ & $3.065 \mathrm{a}$ & $2.191 \mathrm{a}$ & \\
\hline \multicolumn{7}{|c|}{$\mathrm{Vm},\left(\right.$ days $\left.^{-1}\right)$} \\
\hline $\mathrm{RC}$ & $0.672 \mathrm{aA}$ & --- & -- & --- & --- & $0.672 \mathrm{~A}$ \\
\hline RPB & --- & $0.478 \mathrm{aA}$ & $0.437 \mathrm{aA}$ & $0.443 \mathrm{aA}$ & $0.478 \mathrm{aAB}$ & $0.459 \mathrm{~B}$ \\
\hline RPPB & --- & $0.472 \mathrm{abA}$ & $0.508 \mathrm{aA}$ & $0.378 \mathrm{bA}$ & $0.513 \mathrm{aA}$ & $0.467 \mathrm{~B}$ \\
\hline TRPB & --- & $0.477 \mathrm{aA}$ & $0.408 \mathrm{abA}$ & $0.361 \mathrm{bA}$ & $0.390 \mathrm{abB}$ & $0.409 \mathrm{~B}$ \\
\hline TRPPB & --- & $0.471 \mathrm{aA}$ & $0.281 \mathrm{bB}$ & $0.056 \mathrm{cB}$ & $0.055 \mathrm{cC}$ & $0.227 \mathrm{C}$ \\
\hline Average & $0.672 \mathrm{a}$ & $0.475 \mathrm{~b}$ & $0.409 \mathrm{bc}$ & $0.309 \mathrm{~d}$ & $0.380 \mathrm{c}$ & \\
\hline \multicolumn{7}{|c|}{ IVG } \\
\hline $\mathrm{RC}$ & $19.71 \mathrm{aA}$ & --- & --- & --- & --- & $19.71 \mathrm{~A}$ \\
\hline RPB & --- & $11.84 \mathrm{abA}$ & $13.120 \mathrm{aA}$ & $10.48 \mathrm{bA}$ & $12.62 \mathrm{abA}$ & $12.01 \mathrm{~B}$ \\
\hline RPPB & --- & $12.09 \mathrm{abA}$ & $12.910 \mathrm{aA}$ & $10.09 \mathrm{bA}$ & $14.47 \mathrm{aA}$ & 12.39B \\
\hline TRPB & --- & $12.13 \mathrm{aA}$ & $11.02 \mathrm{aAB}$ & $7.83 \mathrm{bB}$ & $10.01 \mathrm{abB}$ & $10.25 \mathrm{C}$ \\
\hline TRPPB & --- & $11.90 \mathrm{aA}$ & $8.80 \mathrm{bB}$ & $0.087 \mathrm{cC}$ & $0.055 \mathrm{cC}$ & $5.554 \mathrm{D}$ \\
\hline Average & $19.71 \mathrm{a}$ & $11.99 \mathrm{~b}$ & $11.46 \mathrm{~b}$ & $9.904 \mathrm{c}$ & $7.124 d$ & \\
\hline
\end{tabular}

Averages followed by the same lowercase letter on the same line, or by the same uppercase letter in the same column, are not significantly different from each other by the Tukey test at a 5\% probability level.

\section{DISCUSSION}

Variations in water content are of fundamental importance in seed storage, especially in terms of carbohydrate metabolism, and seed sugar levels are generally affected by storage temperatures. The quantity of sucrose found in seeds of the legume Caesalpinia echinata Lam. is related to its desiccation tolerance, and high sucrose levels have been reported in viable seeds stored for 18 months at $7^{\circ} \mathrm{C}$ (BARBEDO et al., 2002). Ribeiro (2008) observed that an increase in the water content of Gliricidia sepium seeds initiated a series of reactions that contributed to their deterioration by diminishing their sugar content.
The accumulation of soluble carbohydrates in seeds seems to be involved in desiccation tolerance and the longevity observed in this species.

Permeable wrapping that permit water vapor exchange between the seeds and the atmosphere are more adequate for use in dry environments and for short storage periods (FERREIRA and BORGHETTI, 2004). Freitas et al.(1992) reported that seeds maintained in highly permeable wrappers in humid environments are subject to relatively rapid deterioration. Cisneiros et al. (2003) observed that seeds of Psidium guineense stored in paper sacks increased their water content even when stored in a

Revista Árvore, Viçosa-MG, v.36, n.2, p.229-235, 2012 

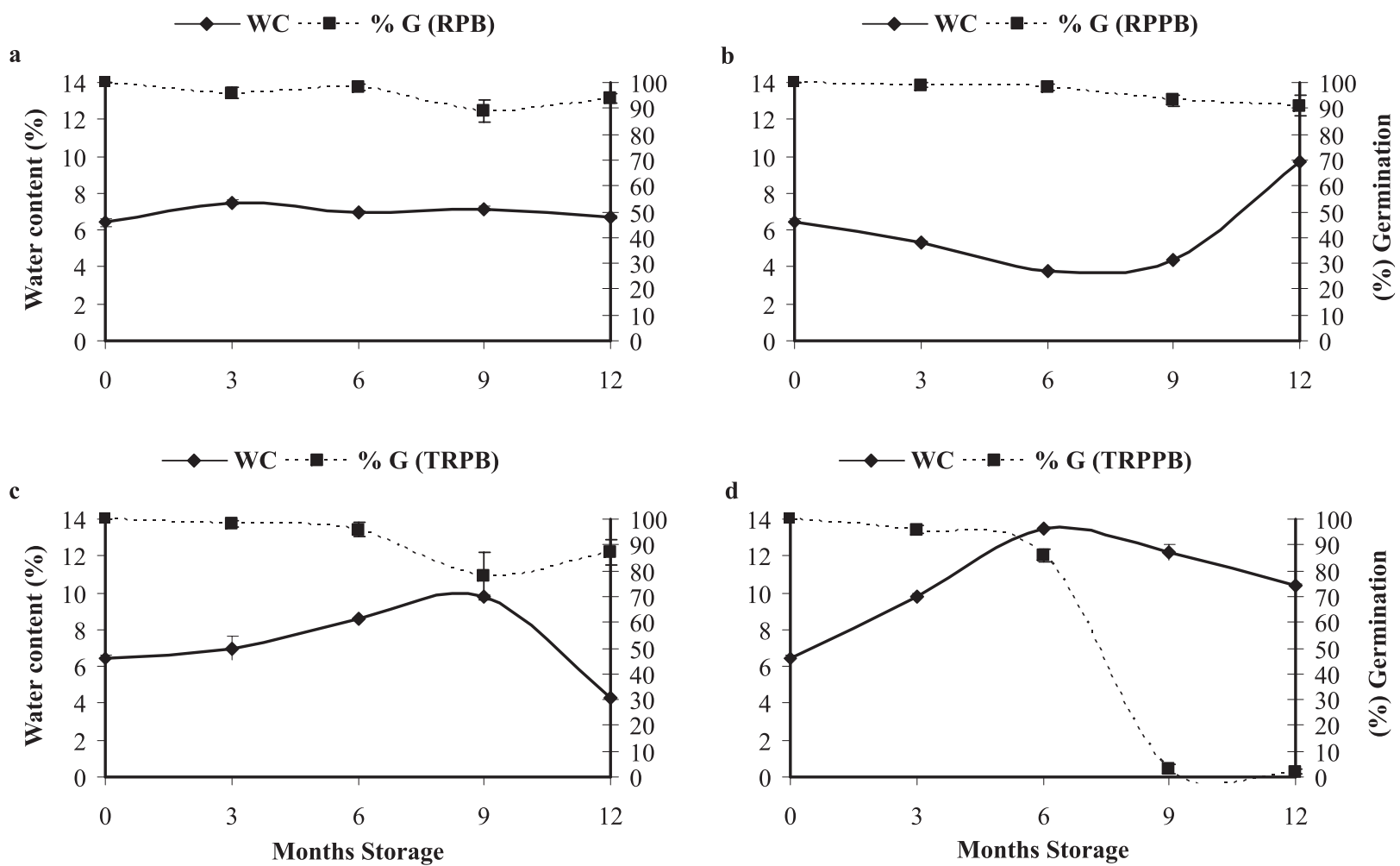

Figure 1 - Water content and germination percentage of the seeds of G. sepium stored in a refrigerator [in plastic bags (RPB) - a or in paper bags (RPPB) - b], or stored at room temperature [in plastic bags (TRPB) - c or in paper bags (TRPPB) - d], during 0, 3, 6, 9, or 12 months. Average of four trials \pm ASE.

Figura 1 - Teor de água e porcentagem de germinação de sementes de G. sepium submetidas ao armazenamento em geladeira [saco plástico (GSPL)- a e papel (GSPP)- b] e no ambiente natural [sacos plástico (ASPL)- c e de papel (ASPP)d] durante 0, 369 e 12 meses. Média de quatro repetições \pm EPM.

freezer, and their ability to germinate became greatly reduced over time. Maluf \& Pisciottano-Ereio (2005) reported that the best condition for storing and conserving seeds of Campomanesia phaea was in plastic bags under controlled cold conditions. Matos et al. (2008) observed that seeds of Apeiba tibourbou stored in plastic bags in cold chambers demonstrated constant germination percentages over different periods of time. Plastic and glass containers (CISNEIROS et al., 2003) act as barriers to gas exchange between the seeds and their external environment, thus reducing their metabolism and retarding their deterioration; these beneficial effects become more accentuated at lower storage temperatures.

The present work established that the physiological quality of gliricidia seeds was affected by the permeability of the packing material used during storage. It is interesting to note, however, that these results are different from those obtained with other species from the semi-arid region, such as Anadenanthera macrocarpa, Pseudobombax simpliciflolium, Myracrodruon urundeuva (SOUZA et al., 1980), and Tabebuia impetiginosa (CABRAL et al., 2003) when stored at low temperatures in either cloth or polyethylene bags under low relative humidity. According to Carvalho and Nakagawa (2000), the type of packing used for seed storage determines their preservation, viability, and vigor, and will depend on the particular environmental conditions under which the seeds will be stored. Cold and dry environments are more favorable for storing orthodox seeds (VILLELA and PERES, 2004).

Germination rate index is one of the most traditional measures of seed vigor (VIEIRA and CARVALHO, 1994), and seed lots with similar germination percentages frequently demonstrate differences in germination rate 
index - indicating differences in physiological vigor (KRZYZANOWKSKI et al., 1999). The changes in germination speed rate observed here in gliricidia seeds stored at room temperature indicated decreasing overall physiological vigor. According to Drumond and Carvalho Filho (1999), gliricidia seeds lose their viability or enter into secondary dormancy after 12 months in storage. Successful conservation of gliricidia seeds is intimately related to their initial water content and the stability of that water content during storage. High viability (that is, a greater degree of tolerance to storage) was maintained under low temperature conditions.

The results obtained in the present study are promising in terms of the conservation of gliricidia seeds, for they indicate that the seeds can be conserved with high viability for reasonably long periods of time (up to 12 months), and even at temperatures near $25^{\circ} \mathrm{C}$, if the initial low water content of the seeds is maintained through the use of impermeable storage containers.

\section{ACKNOWLEDGEMENTS}

The authors would like to thank the Conselho Nacional de Desenvolvimento Científico e Tecnológico (CNPq) and the Fundação de Amparo a Pesquisa do Estado da Bahia (FAPESB) for financial support of this project, and José Juracy for his help with the plant material.

\section{REFERENCES}

BARBEDO, C. J.; BILIA, D. A. C.; FIGUEIREDO-RIBEIRO, R. C. L. Tolerância à dessecação e armazenamento de sementes de Caesalpinia echinata Lam. (pau-brasil).

Revista Brasileira de Botânica, v.25, p.431-439, 2002.

BEWLEY, J. D.; BLACK, M. Seeds: physiology of development and germination. 2.ed. New York: Plenum Press, 1994.

BRASIL. Ministério da Agricultura e da Reforma Agrária. Regras para análise de sementes. Brasília: 1992. 365p.

CABRAL, E. L.; BARBOSA, D. C. A.; SIMABUKURO, E. A. Armazenamento e germinação de sementes de Tabebuia áurea (Manso) Benth. \& Hook. F. Ex. S. Moore. Acta Botânica Brasílica, v.17, n.4, p.609-617, 2003.
CARnEIRO, J. G. A. Armazenamento de sementes florestais. Curitiba: FUPEF, 1985. 35p. (Série Técnica, 14)

CARVALHO, N. M.; NAKAGAWA, A. J.

Sementes: ciência, tecnologia e produção. 4.ed. Jaboticabal: FUNEP, 2000. 588p.

CISNEIROS, R. A. et al. Qualidade fisiológica de sementes de araçazeiro durante o armazenamento. Revista Brasileira de Engenharia Agronômica e Ambiental, v.7, n.3, p.513-518, 2003.

DELOUCHE, J. C. et al. Storage of seed in subtropical and tropical regions. Seed Science and Technology, v.1, n.3, p.671-700, 1973.

DRUMOND, M. A.; CARVALHO FILHO, O. M. Introdução e avaliação de Gliricidia sepium na região semi-árida do Nordeste Brasileiro. In: QUEIRÓZ, M. A.; GOEDERT, C. O.; RAMOS, S. R. R. (Ed.) Recursos genéticos e melhoramento de plantas para o Nordeste brasileiro. Versão 1.0, 1999. Petrolina: Embrapa Semi-Árido /Brasília-DF: Embrapa Recursos Genéticos e Biotecnologia, nov. http://www.cpatsa.embrapa.br.

FERREIRA, D. F. Análises estatísticas por meio do Sisvar para Windows versão 4.0. In: REUNIÃO ANUAL DA REGIÃO BRASILEIRA DA SOCIEDADE INTERNACIONAL DE BIOMETRIA, 45., São Carlos, 2000. Anais... São Carlos: UFS Car, 2000. p.255-258.

FERREIRA, A. G.; BORGHETTI, F. (Orgs.). Germinação- Do básico ao aplicado. Porto Alegre: Artmed, 2004. 323p.

FREITAS, G. B.; SILVA, R. F.; ARAÚJO, E. F. Influência da condição de armazenamento na qualidade de sementes de milho. Revista Brasileira de Armazenamento, v.17, n.1, p.21-26, 1992.

INTERNATIONAL SEEDTESTINGASSOCIATIONISTA. International rules for seed testing: rules 1992. Seed Science and Technology, v.21, p.231, 1993.

KRZYZANOWSKI, F. C.; VIEIRA, R. D.; FRANÇA NETO, J. B. Vigor de Sementes: conceitos e testes. Londrina: ABRATES, 1999. 218p.

MALUF, A. M.; PISCIOTTANO-EREIO, W. A. Secagem e armazenamento de sementes de cambuci. Pesquisa Agropecuária Brasileira, v.40, n.7, p.707-714, 2005. 
MARCOS FILHO, J.; CÍCERO, S. M.; SILVA, W. R. Avaliação da qualidade das sementes. Piracicaba: FEALQ, 1987. 230p.

MATOS, V. P. et al. Efeito do tipo de embalagem e do ambiente de armazenamento sobre a germinação e o vigor das sementes de Apeiba tibourbou AUBL. Revista Árvore, v.32, n.4, p.617-625, 2008.

MATTHEWS, S. Physiology of seed ageing. Outlook on Agriculture, v.14, n.2, p.19-23, 1985.

MELO, J. T.; RIBEIRO, J. F.; LIMA, V. L. G. F. Germinação de sementes de algumas espécies arbóreas nativas do cerrado. Revista Brasileira de Sementes, v.1, n.2, p.8-12, 1979.

NODARI, R. O. et al. Conservação de frutos e sementes de palmiteiro (Euterpe edulis Martius) sob diferentes condições de armazenamento.

Revista Árvore, v.22, n.1, p.1-10, 1998.

RIBEIRO, R. C. Efeito do Armazenamento na Qualidade Fisiológica de Sementes de Gliricidia sepium (Jacq.) Steud.

(LEGUMINOSAE

PAPILIONOIDEAE). 2008. 100f. Dissertação (Mestrado em Botânica), Universidade Estadual de Feira de Santana, Feira de Santana, 2008.
SANTANA, P. J. A. Maturação, secagem e armazenamento de sementes de espécies de Eugenia (Myrtaceae). 2007. 81f. Dissertação (Mestrado em Biodiversidade Vegetal e Meio Ambiente)- Instituto de Botânica da Secretaria do Meio Ambiente, São Paulo, 2007.

SOUZA, S. M.; PIRES, I. E.; LIMA, P. C. F. Influência da embalagem e condições de armazenamento na longevidade de sementes florestais. In: PESQUISA Florestal no Nordeste Semi-árido: sementes e mudas. Petrolina: Embrapa-CPATSA, 1980. p.15-24. (Boletim de Pesquisa, 2)

VIEIRA, R. D.; CARVALHO, N. M. Testes de vigor em sementes. Jaboticabal: FUNEP, 1994. 164p.

VILLELA, F. A.; PERES, W. B. Coleta, beneficiamento e armazenamento. In: FERREIRA, A. G.; BORGHETTI, F. (Ed.) Germinação: do básico ao aplicado. Porto Alegre: Artmed, 2004. p.265-281.

WARD, F. H.; POWELL, A. A. Evidence for repair processes in onion seeds during storage at high seed moisture contents. Journal Experimental Botany, v.34, n.140, p.277-282, 1983. 
